\title{
Osteogenesis imperfecta: current issues of etiology, pathogenesis, classification (systematic review)
}

\author{
S.O. Ryabykh, D.A. Popkov, E.N. Shchurova, P.V. Ochirova, T.V. Ryabykh
}

Ilizarov National Medical Research Centre for Traumatology and Orthopedics, Kurgan, Russian Federation

\begin{abstract}
The constantly changing information about the genetic nature of osteogenesis imperfecta (OI), new approaches to classification and diagnosis, and the growing interest in this pathology require careful analysis and generalization of the available data in the recent literature. Purpose Analysis of recent literature on epidemiology, pathogenesis, etiology, classification of osteogenesis imperfecta. Materials and methods The literature search was carried out in the scientific literature databases of PubMed, Web of Science, Scopus, eLIBRARY, RSCI, and references of the key works. The following inclusion criteria were used: literature reviews, review articles, multicenter studies, cohort studies of patients with osteogenesis imperfecta. Results This systematic review included 18 publications that met the inclusion criteria. All selected publications were published within the period from 2012 to 2020 . The study designs were review articles or literature reviews. Discussion Osteogenesis imperfecta is one of the most common types of skeletal dysplasia, a phenotypically and genetically heterogeneous group of hereditary bone diseases. OI is characterized by high variability of manifestations, even within the same type and one family. The results of the analysis of the prevalence of this disease in different population groups remain not fully covered. The degree of genetic heterogeneity of the disease has not yet been determined. Research is ongoing to identify new genes involved in the pathogenesis of OI. The introduction of modern methods for determining mutations in genes contributed to the progress of research into the molecular pathogenesis of osteogenesis imperfecta, and identification of new genes, mutations in which lead to OI. The large number of causative genes complicates the process of creating an optimal classification of OI. The difficulty of creating a comprehensive classification of OI subtypes is the fact that there is no clear phenotype-genotype relationship; based on the mutation, conclusions about its clinical severity cannot be drawn. Conclusion The classification of various types of osteogenesis imperfecta is still the subject of ongoing debate and research.

Keywords: osteogenesis imperfecta, epidemiology, etiology, pathogenesis, classification
\end{abstract}

\section{INTRODUCTION}

Osteogenesis imperfecta (OI) is known as a brittle bone disease, a phenotypically and genetically heterogeneous group of hereditary bone dysplasias $[1,2]$. It is a hereditary generalized heterogeneous connective tissue condition that mainly affects bones, ligaments, dentin, and sclera [3-7]. The incidence of OI is $1 / 10,000-1 / 20,000$, which makes this disease one of the most common skeletal dysplasias [8-10].

The growing interest in this pathology over the past ten years has been evidenced by several recent publications, which provide excellent reviews of the pathophysiology and genetics of OI and related diseases $[3,4,11,12]$.

Osteogenesis imperfecta is a heterogeneous disease, the severity of which varies from a slight increase in the frequency of fractures to death in the perinatal period [1]. People with osteogenesis imperfecta have reduced bone mass and bone fragility resulting in fractures of long bones and compression of vertebrae, various deformities of long bones, ribs and spine, and significant growth deficit $[2,7,13,14]$.

Typical clinical descriptions of patients with osteogenesis imperfecta may also include blue or gray scleral coloration, dental abnormalities called dentinogenesis imperfecta [4, 15], joint hypermobility, ligamentous laxity $[3,14,16]$, hearing loss, and some others. But these non-skeletal features may often be absent [3]. The clinical manifestations of osteogenesis imperfecta vary considerably. The appearance of patients can vary significantly even within the same OI type $[17,18]$.

Constant widening of the information about the genetic nature of osteogenesis imperfecta $[2-5,7,19$, $20]$, new approaches to classification and diagnosis $[3,21-24]$ and the growing interest in this pathology require careful analysis and generalization of the data available in the current literature.

The aim of this work was to analyze the current literature on epidemiology, pathogenesis, etiology, classification of osteogenesis imperfecta.

\section{MATERIAL AND METHODS}

A search of literature in English, Russian and German was carried out in the electronic databases PubMed, Web of Science, Cochrane Library, E-library. References from the studies found were also analyzed. We selected articles published in the period from 2010 to 2021 .

The following inclusion criteria were used: literature reviews, review articles, multicenter studies,

[al Ryabykh S.O., Popkov D.A., Shchurova E.N., Ochirova P.V., Ryabykh T.V. Osteogenesis imperfecta: current issues of etiology, pathogenesis, classification (systematic review). Genij Ortopedii, 2021, vol. 27, no 4, pp. 453-460. DOI 10.18019/1028-4427-2021-274-453-460 
controlled cohort studies, uncontrolled cohort studies, case-control studies of patients with osteogenesis imperfecta.

Search keywords were: osteogenesis imperfecta, epidemiology of osteogenesis imperfecta, etiology and pathogenesis of osteogenesis imperfecta, classification of osteogenesis imperfecta.

Exclusion criteria were: animal studies, case reports or case series, abstracts, conference proceedings, republications.
The study was carried out in accordance with international guidelines for writing systematic reviews and PRISMA checklist for meta-analyses [25]. First, we searched for literature sources using keywords, reviewed abstracts of the articles found and excluded publications that did not meet the criteria. At the final stage, full texts of the selected articles were analyzed for compliance with the inclusion criteria and the list of references for the presence of relevant studies (Fig. 1).

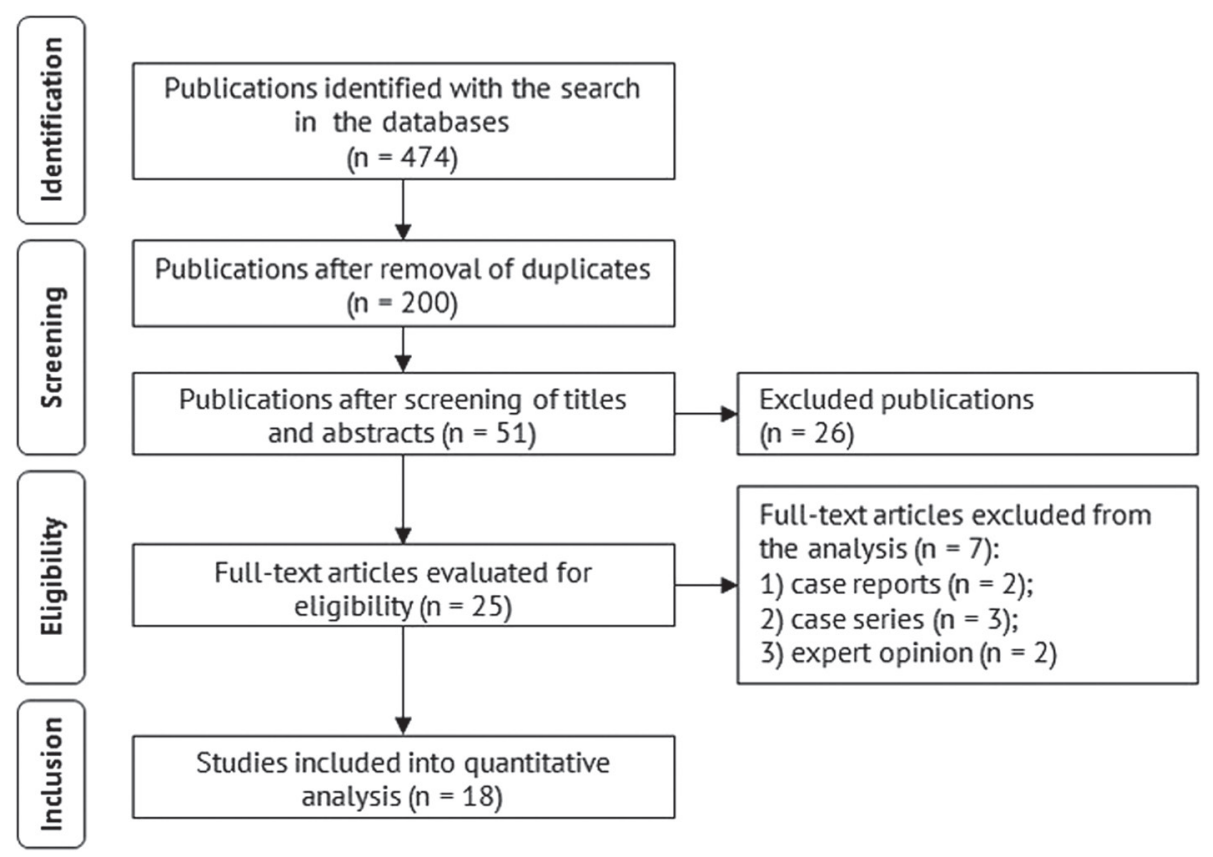

Fig. 1 Search strategy and selection of literature data for inclusion in a systematic review

\section{RESULTS}

This systematic review included 18 publications. All selected according to the inclusion criteria studies were published between 2012 and 2020 and were either review articles or literature reviews. The geography of publications was wide enough (Table 1).

Table 1

Articles included into analysis

\begin{tabular}{|l|c|c|c|}
\hline \multicolumn{1}{|c|}{ Authors } & Year of publication & Country, town & Study design \\
\hline Forlino et al. [15] & 2012 & USA, Bethesda & Review \\
\hline Biggin, Munns [26] & 2014 & Australia, Westmead & Review \\
\hline Marini et al. [27] & 2013 & USA, Bethesda & Review \\
\hline Salzmann et al. [17] & 2014 & Germany, Munich & Review \\
\hline Hoyer-Kuhn et al. [18] & 2015 & Germany, Cologne & Review \\
\hline Bourgeois et al. [28] & 2016 & Switzerland, Lausanne & Review \\
\hline Forlino et al. [4 ] & 2016 & Italy, Pavia & Review \\
\hline Trejo et al. [3] & 2016 & Canada, Quebec & Review \\
\hline Liu et al. [5] & 2017 & China, Beijing & Review \\
\hline Marini et al. [2] & 2017 & USA, Bethesda & Review \\
\hline Palomo et al. [6] & 2017 & Brazil, Sao Paulo & Review \\
\hline EypцeB c coaBT. [29] & 2019 & Russia, Moscow & Review of literature \\
\hline Cho et al. [30] & 2020 & Germany, Korea, Seoul & Review \\
\hline Gehlen et al. [14] & 2020 & USA, Marshfield & Review \\
\hline Steiner et al [31] & 2020 & Russia, Ufa & Review \\
\hline Zaripova et al. [23] & 2020 & USA, Bethesda & Review of literature \\
\hline Marini,Dang Do et al. [20] & 2020 & USA & Review \\
\hline Marom et al. [24] & 2020 & & Review \\
\hline
\end{tabular}




\section{Epidemiology}

Osteogenesis imperfecta is one of the most common skeletal dysplasias. OI occurs in approximately $1 / 10,000-1 / 20,000$ newborns [8-10, 32]. It is a genetically heterogeneous skeletal dysplasia with a higher mortality rate than in the general population [6].

The results of studies conducted in Europe and the United States have shown that the prevalence of osteogenesis imperfecta at birth is $0.3-0.7$ per 10,000 births $[33,34]$. These neonatal cohort studies reflect severe types of osteogenesis imperfecta and do not include the milder types that become apparent after birth.

A population study using the Danish National Patient Registry showed that the annual incidence of osteogenesis imperfecta between 1997 and 2013 was 1.5 per 10,000 births [35].

Population surveys in the countries with large medical databases, such as Finland, found an incidence of about 0.5 per 10,000 [36], most of them were phenotypically milder osteogenesis imperfecta types (types I and IV).

Since these cohort and population surveys at birth are based on clinical data and tend to identify mutually exclusive populations, an acceptable incidence of osteogenesis imperfecta is about $1 / 10,000$ [2].

In the populations with a high level of consanguinity or a large number of carriers, the incidence of osteogenesis imperfecta is higher than in unrelated populations [37-39]. For example, among African Americans in the United States, the carrier frequency for one pathogenic variant in $\mathrm{P} 3 \mathrm{H} 1$ is approximately 1 per 240 individuals [38].

\section{Etiology and pathogenesis of osteogenesis imperfecta}

Mutations in the genes encoding type I collagen (COL1A1 and COL1A2) are the most common causes of osteogenesis imperfecta $[2,21,40]$. Type I collagen is a heterotrimer protein containing two $\alpha 1(\mathrm{I})$ and one $\alpha 2(\mathrm{I})$ chains [21]. It is synthesized as a procollagen molecule and undergoes many posttranslational modifications. Flanking propeptides are removed by specific proteases; then the molecule is spontaneously assembled into fibrils in the tissue and then stabilized by cross-linking [4, 6, 21].

The resulting mutations lead to negative shifts in the $\alpha$-chain, disorders in post-translational modification, and cross-linking of collagen molecules into fibrils [4, $40,41]$. The result of these events is altered collagen fibers and disorders in the bone tissue structure.

It cannot be ruled out that these changes may contribute to negative deviations in the process of bone tissue remodeling (its acceleration) [19].

According to most authors, osteogenesis imperfecta develops due to autosomal dominant mutations in the COL1A1 and COL1A2 genes in $70-90 \%$ of cases which lead to quantitative and qualitative changes in type I collagen $[2,4,21,40]$. With quantitative shifts, the structure of collagen is preserved but its amount is reduced almost by half.

More than $80 \%$ of mutations that change the structure of type I collagen are changes in one base pair, leading to substitutions of glycine residues in the $\alpha 1$ (I) or $\alpha 2$ (I) chain. The larger side chain of the substitution residue causes a delay in helical folding and subsequent post-translational overmodification of lysine and proline residues along the helical site. Phenotypic expression depends on amino acid substitution, chain and position $[4,40]$.

The study of the genome of patients with OI in the last twenty years has shown the presence of other causes in the development of this disease, that are defects in the genes of proteins that interact with collagen for folding or post-translational modifications $[4,19]$. Disorders in bone formation were identified that were not associated with collagen, but were caused by impaired bone mineralization, functioning and differentiation of osteoblasts [4].

Apart from the autosomal dominant inheritance, $\mathrm{X}$-linked, autosomal recessive, and additional pathways have been identified.

In 2000, the first mutation not associated with collagen synthesis in the IFITM5 gene with an autosomal dominant inheritance pathway was identified $[21,42,43]$. A characteristic feature of this mutation was the formation of hypertrophic callus and ossification of the interosseous membrane. In 2006 R. Morello et al described the first mutation with an autosomal recessive inheritance in the CRTAP gene [44].

Currently, the study of the genome in the families of OI patients has identified the presence of more than 20 genes, mutations in which lead to various forms of OI [7, 23]. More than 1,500 mutations have been identified and registered in the OI database [45].

According to T.J. Cho et al [30], given the multitude of causal genes and their phenotypic similarities, it is advisable to test all known OI genes simultaneously. The authors performed molecular genetic analysis using next-generation sequencing and/or Sanger sequencing in 177 Korean OI patients and found that 96 patients (54\%) had COL1A1 mutations, 39 (22\%) COL1A2, $10(6 \%)$ IFITM5, $5(3 \%)$ FKBP10, 1 BMP1 and 1 WNT1, and no mutations were found in 25 patients (14\%). The authors concluded that $88 \%$ of all identified mutations were associated with type I collagen genes, compared with $6.6 \%$ of IFITM5 (type V) cases and $4.6 \%$ of autosomal recessive cases in the surveyed cohort of patients.

\section{Classification of osteogenesis imperfecta}

Osteogenesis imperfecta is a heterogeneous disease, the severity of which varies from a slight increase in the frequency of fractures to death in the perinatal 
period $[1,26]$. Therefore, when planning its treatment, it is necessary to classify all subtypes. The difficulty of creating a comprehensive classification of OI subtypes is that there is no clear phenotype-genotype relationship; based on the mutation, conclusions about clinical severity cannot be drawn $[14,26]$.

In addition, the introduction of modern nextgeneration sequencing technologies (NGS) contributed to the progress of research into the molecular pathogenesis of osteogenesis imperfecta, the identification of new genes, mutations in which can lead to OI (about 20 genes). A large number of causative genes complicate creation of an optimal OI classification [23].

D.O. Sillence (1979) proposed the first OI classification, based on clinical, radiological and genetic features of patients that included four types I, II, III, IV [46]. All of them are caused by autosomal dominant mutations in the COL1A1 and COL1A2 genes, which are responsible for the synthesis of type I collagen. The OI distribution may be represented as follows: I $<$ IV $<$ III $<$ II. However, many authors note that $\mathrm{OI}$ is characterized by high variability of manifestations even within one type and one family $[1,2,4,47,48]$.

Currently, the Sillence classification (OI types I, II, III, IV) has been still used much in the practical work $[7,28,29,30]$.

OI type $\mathrm{I}$ is a non-deforming and the mildest OI form with distinctly blue sclera. It is the most common type in the world with the exception of some isolated unique populations in which rare recessive types are more common [31]. Incidence of fractures is relatively low and decreases in the period of sexual maturation while severe deformities are rare. The patients' stature is usually normal or slightly below average. There is predisposition to progression of hearing loss that may start in the adolescent age and progress throughout life [21]. This type is autosomal dominant inheritance.

OI type II is perinatal lethal and patients die soon after birth. Multiple fractures are identified at the stage of intrauterine development [49]. Typically, these patients have short and misshapen limbs, blue or gray sclera. They die due to respiratory failure [50]. OI type II usually results from heterozygous mutations in type I collagen genes, but the phenotypic presentation is similar to some forms of OI caused by biallelic mutations (recessively inherited) in noncollagen genes (CRTAP, P3H1, PPIB, TMEM38B, CREB3L1, and others). Repetition in families may result from recessive inheritance or, in some cases, parental mosaicism of a causal dominant mutation in the type I collagen gene.

OI type III is a progressively deforming type, and the patients are the most severely affected survivors with blue sclera. They present with numerous, almost uncountable fractures from birth [51], frequently leading to severe limb deformity if not aggressively managed. Patients show profound short stature. They feature imperfect dentinogenesis, platybasia, basilar impression, compression of the vertebral bodies, scoliosis. The shape of the face is often triangular, with prominent frontal tubercles, blue or gray sclera. Life expectancy is reduced due to pulmonary insufficiency. Inheritance is usually autosomal dominant due to mutations in type I collagen genes, but biallelic mutations in non-collagen genes (recessive inheritance) have been proven in some individuals who were originally referred by clinical classification to this group.

OI type IV is of moderate severity and has a wide phenotypic range, overlapping types I and III. Most patients are able to walk but the number of fractures is counted by dozens. The patients with this type of disease feature growth variability, basilar impression, imperfect dentinogenesis, and hearing impairment. The formation of OI type IV is a consequence of mutations in the genes of type I collagen (COL1A1 and COL1A2) with autosomal dominant inheritance.

In 2000, the classification was supplemented with type $\mathrm{V}$ which is characterized by moderate to severe bone fragility. A distinctive feature of this type is the formation of hypertrophic callus (after fractures or surgery) and ossification of the interosseous membrane in the forearm, which can lead to secondary dislocation of the radial head [52]. Type $\mathrm{V}$ osteogenesis imperfecta has an autosomal dominant pattern and is caused by repeated mutation that results in the addition of five amino acids at the amino acid terminal of a protein that interferes with function.

Osteogenesis imperfecta has been known since the early 1980 s as a dominantly inherited disease caused by mutations in any of the genes encoding type I collagen (COL1A1 and COL1A2), a major component of the extracellular matrix of bone and skin [40].

Since 2006, it has been determined that new mutations in genes associated with collagen have different types of inheritance and form osteogenesis imperfecta $[2,4]$. The identification of these new causal genes led to the adaptation of the original classification system for osteogenesis imperfecta to the new results of genetic studies. Both clinical and genetic classifications have appeared, covering rare forms of osteogenesis imperfecta, since most of the new genes do not have specific diagnostic features.

In the clinical classification, new forms of the disorder have been grouped into Sillence's types from I to IV in terms of their clinical severity. Type II osteogenesis imperfecta, a perinatal lethal form, included lethal collagen mutations and some CRTAP, 
LEPRE1, PPIB, SERPINH1, and SP7 mutations [27]. Some clinical classifications have retained types V, VI, and VII, which were originally designated clinically [54].

In the same type, individuals may have a dominant or recessive inheritance, which makes genetic counseling difficult and makes it difficult to investigate the disease mechanism and response to therapy. This classification leads to many incompatible situations, including re-typing the individual by severity over the course of his life and siblings with different types of osteogenesis imperfecta.

In the genetic classification, the Sillence types have been used only for collagen mutations, and the numbering continues for each new discovery in genes [27]. This pattern eliminates the problems mentioned above and provides a better organization of research and clinical management than the clinical classification. However, genetic classification has the disadvantage of an ever-changing list that can be difficult for geneticists and parents to use if it exceeds a dozen of types. To meet both clinical and genetic requirements, Forlino et al suggested [4] that the functional metabolic classification will have the widest application and at the same time will preserve the numbering of genetic types.

This rearrangement for Ehlers-Danlos syndrome by function has been successful for both clinicians and families [55]. In this regard, genes whose products act in the same way and probably have common mechanisms are combined into five functional groups: 1) defects in the structure or processing of collagen (COL1A1, COL1A2 and BMP1) - group A; 2) collagen modification defects (CRTAP, LEPRE1, PPIB and TMEM38B) - group B; 3) collagen folding and cross-linking defects (SERPINH1, FKBP10 and PLOD2) - group C; 4) ossification or mineralization defects (IFITM5 and SERPINF1) - group D; 5) developmental defects of osteoblasts with collagen deficiency (WNT1, CREB3L1 and SP7) - group E. The Functional genetic classification may usefully be supplemented by a parallel clinical severity score [56].

Thus, increased information about the genetic nature of osteogenesis imperfecta has led to the emergence of two new approaches to classification: 1) a more clinically grounded approach, in which new recessive types are placed under the "clinical umbrella" of the Sillence types; 2) a genetic functional approach, in which the Sillence types (I-IV) are reserved for mutations in COL1A1 or COL1A2, and new genes are assigned additional type numbers based on the mutation without clinical correlation [2].

However, the use of these classifications in clinical practice is difficult due to the absence of pronounced differences between the newly identified types of OI and the four Sillence classical types.
They have been criticized by clinicians and researchers $[4,55]$. The "Nosology and Classification of Genetic Skeletal Disorders", published in 2015, adopted a phenotypic criterion for the classification of osteogenesis imperfecta, limited to five types (types of osteogenesis imperfecta 1-5) $[3,57,58]$.

T. Palomo et al [6] believe that it is more optimal to describe the types of osteogenesis imperfecta, indicating the phenotypic severity and the involved gene, as suggested by F.S. Van Dijk et al $[3,21]$. In 2019, this classification was modified ("Nosology and Classification of Genetic Skeletal Disorder") (Table 2) [22].

Table 2

Classification of osteogenesis imperfecta (modified according to G. Mortier et al [22])

\begin{tabular}{|c|c|c|}
\hline OI type & Inheritance & Gene \\
\hline $\begin{array}{l}\text { Type 1: } \\
\text { No deformities, blue sclera }\end{array}$ & $\mathrm{AD}$ & $\begin{array}{l}\text { COL1A1 } \\
\text { COL1A2 }\end{array}$ \\
\hline \multirow{5}{*}{$\begin{array}{l}\text { Type 2: } \\
\text { Perinatal lethal type }\end{array}$} & $\mathrm{AD}$ & COL1A1 \\
\hline & $\mathrm{AD}$ & COL1A2 \\
\hline & AR & CRTAP \\
\hline & AR & LEPRE1 \\
\hline & AR & PPIB \\
\hline \multirow{15}{*}{$\begin{array}{l}\text { Type 3: } \\
\text { Progressive type associated with } \\
\text { bone deformities }\end{array}$} & $\mathrm{AD}$ & COL1A1 \\
\hline & $\mathrm{AD}$ & COL1A2 \\
\hline & $\mathrm{AD}$ & IFITM5 \\
\hline & $\mathrm{AR}$ & SERPINF1 \\
\hline & AR & CRTAP \\
\hline & AR & LEPRE1 \\
\hline & $\mathrm{AR}$ & PPIB \\
\hline & AR & SERPINH1 \\
\hline & AR & FKBP10 \\
\hline & AR & TMEM38B \\
\hline & AR & BMP1 \\
\hline & AR & WNT1 \\
\hline & $\mathrm{AR}$ & CREB3L1 \\
\hline & AR & SPARC \\
\hline & AR & TENT5A \\
\hline \multirow{8}{*}{$\begin{array}{l}\text { Type 4: Mainly moderate form, } \\
\text { normal sclera }\end{array}$} & $\mathrm{AD}$ & COL1A1 \\
\hline & $\mathrm{AD}$ & COL1A2 \\
\hline & $\mathrm{AD}$ & WNT1 \\
\hline & $\mathrm{AD}$ & IFITM5 \\
\hline & $\mathrm{AR}$ & CRTAP \\
\hline & AR & PPIB \\
\hline & $\mathrm{AR}$ & FKBP10 \\
\hline & AR & SP7 \\
\hline $\begin{array}{l}\text { Type 5: } \\
\text { Calcification of the interosseous } \\
\text { membranes, hypertrophic callus }\end{array}$ & $\mathrm{AD}$ & IFITM5 \\
\hline
\end{tabular}

Notes: AD - autosomal dominant; AR - autosomal recessive

Separate OI types according to this classification are clinically characterized as follows [14]:

- OI type 1 is the mildest type, by which deformities of long bones do not occur. Most of the sufferers are almost "normal". Fractures most often occur in the period of the burst in the adolescence. Hearing impairment is common in young people. Laxity of the 
ligaments with excessive stretching of the joints and decreased muscle tone are usually observed. The sclera is bluish in color. Teeth are rarely affected. In some people, the diagnosis is made in adulthood $[2,59]$.

- OI type 2 is the most severe OI form. Fractures usually occur in utero. Its course usually ends in perinatal death $[2,59]$.

- OI type 3 has the most severe clinical course and OI patients in their life are prone to the development of severe bone deformity. The diagnosis is usually made at birth. Deformities affect the long bones and skull (relative macrocephaly). Scoliosis and deformity of the chest (barrel chest) lead to breathing problems. Patients are very short (sometimes less than $1 \mathrm{~m}$ ) and mostly use a wheelchair. They are prone to a large number of fractures, often more than 200. Hearing is often impaired. In many cases, patients require multiple surgeries in the childhood. Telescopic intramedullary rods are placed in the long bones of children during the growth period. Surgeries are required if scoliosis progresses. The sclera is mostly blue. Basilar platybasia is not uncommon. Neurological complications are possible [2, 59].

-OI type 4 is very variable in clinical manifestations. Patients are of short stature but the decrease is less pronounced than in type 3 patients. Deformities of the skeletal system are also less pronounced than in type 3. Scoliosis is almost always present. Basilar platybasia may occur, but it is less common and less pronounced than in type 3 . Many patients are able to walk with crutches or only occasionally need a wheelchair. Sclera in most cases is of normal color [2, 59].

- OI type 5 typically shows the formation of hyperplastic calluses (after fractures and surgical interventions), calcification of the membranes between the bones without signs of fracture. Syndesmoses on the forearm and lower leg are especially affected. Patients should avoid pro- and supination movements of the forearm or foot. This type is characterized by moderate dysplasia, which causes primary defects in ossification or mineralization of the endochondral bone, poor bone quality, spinal deformities, including scoliosis. Radiographic examination should be performed in order to undoubtedly refer the patient to this phenotype $[3,22,28,57,60]$.

The classification of osteogenesis imperfecta types is still the subject of discussion and research. There is an acute issue of creating a classification scheme that does not change the criteria for new OI types [2, 23].

\section{CONCLUSION}

Osteogenesis imperfecta is one of the most common skeletal dysplasias, a phenotypically and genetically heterogeneous group of hereditary bone diseases. It is characterized by high variability of manifestations, even within the same type and one family. The results of the analysis of the prevalence of this disease and its varying types in different groups of the population in different regions of the world remain unclear. The degree of genetic heterogeneity of the disease has not been determined yet. Research is ongoing to identify new genes involved in the OI pathogenesis. The introduction of modern methods for determining mutations in genes contributed to the progress of research into the molecular pathogenesis of osteogenesis imperfecta, the identification of new genes, mutations in which lead to OI.

The large number of causative genes complicates the process of creating an optimal OI classification. The difficulty in creating a comprehensive classification of OI subtypes is that there is no clear phenotype-genotype relationship; based on the mutation, conclusions about clinical severity cannot be drawn. The classification of the varying types of osteogenesis imperfecta is still the subject of ongoing debate and research.

\section{REFERENCES}

1. Rauch F., Glorieux F.H. Osteogenesis imperfecta. Lancet, 2004, vol. 363, no. 9418, pp. 1377-1385. DOI: 10.1016/S0140-6736(04)16051-0.

2. Marini J.C., Forlino A., Bächinger H.P., Bishop N.J., Byers P.H., Paepe A., Fassier F., Fratzl-Zelman N., Kozloff K.M., Krakow D., Montpetit K., Semler O. Osteogenesis imperfecta. Nat. Rev. Dis. Primers, 2017, vol. 3, pp. 17052. DOI: 10.1038/nrdp.2017.52.

3. Trejo P., Rauch F. Osteogenesis imperfecta in children and adolescents - new developments in diagnosis and treatment. Osteoporos. Int., 2016, vol. 27, no. 12, pp. 3427-3437. DOI: 10.1007/s00198-016-3723-3.

4. Forlino A., Marini J.C. Osteogenesis imperfecta. Lancet, 2016, vol. 387, no. 10028, pp. 1657-1671. DOI: 10.1016/S0140-6736(15)00728-X.

5. Liu G., Chen J., Zhou Y., Zuo Y., Liu S., Chen W., Wu Z., Wu N. The genetic implication of scoliosis in osteogenesis imperfecta: a review. J. Spine Surg., 2017, vol. 3, no. 4, pp. 666-678. DOI: 10.21037/jss.2017.10.01.

6. Palomo T., Vilaça T., Lazaretti-Castro M. Osteogenesis imperfecta: diagnosis and treatment. Curr. Opin. Endocrinol. Diabetes Obes., 2017, vol. 24, no. 6, pp. 381-388. https://doi.org/10.1097/MED.0000000000000367.

7. Byers P.H., Rustad C.F. Introduction to Osteogenesis Imperfecta. In: Osteogenesis Imperfecta. Kruse R.W., editor. Springer Nature Switzerland AG. 2020. DOI: $10.1007 / 978-3-030-42527-2$ 1.

8. Andersen P.E. Jr., Hauge M. Osteogenesis imperfecta: a genetic, radiological, and epidemiological study. Clin. Genet., 1989, vol. 36, no. 4, pp. 250255. DOI: 10.1111/j.1399-0004.1989.tb03198.x.

9. Van Dijk F.S., Pals G., Van Rijn R.R., Nikkels P.G., Cobben J.M. Classification of osteogenesis imperfecta revisited. Eur. J. Med. Genet., 2010, vol. 53, no. 1, pp. 1-5. DOI: 10.1016/j.ejmg.2009.10.007.

10. Lindahl K., Åström E., Rubin C.J., Grigelioniene G., Malmgren B., Ljunggren Ö., Kindmark A. Genetic epidemiology, prevalence, and genotypephenotype correlations in the Swedish population with osteogenesis imperfecta. Eur. J. Hum. Genet., 2015, vol. 23, no. 8, pp. 1042-1050. DOI: 10.1038 /ejhg.2015.81.

11. Hendrickx G., Boudin E., Van Hul W. A look behind the scenes: the risk and pathogenesis of primary osteoporosis. Nat. Rev. Rheumatol., 2015, vol. 11, no. 8, pp. 462-474. DOI: 10.1038/nrrheum.2015.48. 
12. Rivadeneira F., Mäkitie O. Osteoporosis and bone mass disorders: from gene pathways to treatments. Trends Endocrinol. Metab., 2016, vol. 27, no. 5, pp. 262-281. DOI: 10.1016/j.tem.2016.03.006.

13. Barber L.A., Abbott C., Nakhate V., Do A.N.D., Blissett A.R., Marini J.C. Longitudinal growth curves for children with classical osteogenesis imperfecta (types III and IV) caused by structural pathogenic variants in type I collagen. Genet. Med., 2019, vol. 21, no. 5, pp. 1233-1239. DOI: $10.1038 / \mathrm{s} 41436-018-0307-y$.

14. Gehlen M., Schwarz-Eywill M., Hinz C., Pfeifer M., Siebers-Renelt U., Ratanski M., Maier A. Rehabilitation seltener Erkrankungen im Erwachsenenalter: Osteogenesis imperfecta [Rehabilitation of orphan diseases in adulthood: osteogenesis imperfecta]. Z. Rheumatol., 2021, vol. 80, no. 1, pp. 29-42. (in German) DOI: 10.1007/s00393-020-00927-8.

15. Forlino A., Cabral W.A., Barnes A.M., Marini J.C. New perspectives on osteogenesis imperfecta. Nat. Rev. Endocrinol., 2011, vol. 7, no. 9, pp. 540557. DOI: $10.1038 /$ nrendo.2011.81.

16. Arponen H., Mäkitie O., Waltimo-Sirén J. Association between joint hypermobility, scoliosis, and cranial base anomalies in pediatric osteogenesis imperfecta patients: a retrospective cross-sectional study. BMC Musculoskelet. Disord., 2014, vol. 15, pp. 428. DOI: 10.1186/1471-2474-15-428.

17. Salzmann M., Krohn C., Berger N. Osteognesis imperfecta [Osteogenesis imperfecta]. Orthopäde, 2014, vol. 43, no. 8, pp. 764-771. DOI: 10.1007/ s00132-013-2229-3. (in German)

18. Hoyer-Kuhn H., Netzer C., Semler O. Osteogenesis imperfecta: pathophysiology and treatment. Wien Med. Wochenschr., 2015, vol. 165, no. 13-14, pp. 278-284. DOI: 10.1007/s10354-015-0361-x.

19. Bacon S., Crowley R. Developments in rare bone diseases and mineral disorders. Ther. Adv. Chronic Dis., 2018, vol. 9, no. 1, pp. 51-60. DOI: 10.1177/ 2040622317739538.

20. Marini J.C., Dang Do A.N. Osteogenesis Imperfecta. In: Endotext [Internet]. K.R. Feingold, B. Anawalt, A. Boyce, G. Chrousos, W.W. de Herder, K. Dhatariya, K. Dungan, A. Grossman, J.M. Hershman, J. Hofland, S. Kalra, G. Kaltsas, C. Koch, P. Kopp, M. Korbonits, C.S. Kovacs, W. Kuohung, B. Laferrère, E.A. McGee, R. McLachlan, J.E. Morley, M. New, J. Purnell, R. Sahay, F. Singer, C.A. Stratakis, D.L. Trence, D.P. Wilson, editors. South Dartmouth (MA): MDText.com, Inc. 2000.

21. Van Dijk F.S., Sillence D.O. Osteogenesis imperfecta: clinical diagnosis, nomenclature and severity assessment. Am. J. Med. Genet. A, 2014, vol. 164A, no. 6, pp. 1470-1481. DOI: 10.1002/ajmg.a.36545.

22. Mortier G.R., Cohn D.H., Cormier-Daire V., Hall C., Krakow D., Mundlos S., Nishimura G., Robertson S., Sangiorgi L., Savarirayan R., Sillence D., Superti-Furga A., Unger S., Warman M.L. Nosology and classification of genetic skeletal disorders: 2019 revision. Am. J. Med. Genet. A, 2019, vol. 179 , no. 12, pp. 2393-2419. DOI: 10.1002/ajmg.a.61366.

23. Zaripova A.R., Khusainova R.I. Modern classification and molecular-genetic aspects of osteogenesis imperfecta. Vavilovskii Zhurnal Genet. Selektsii, 2020, vol. 24, no. 2, pp. 219-227. DOI: 10.18699/VJ20.614

24. Marom R., Rabenhorst B.M., Morello R. Osteogenesis imperfecta: an update on clinical features and therapies. Eur. J. Endocrinol., 2020, vol. 183, no. 4, pp. R95-R106. DOI: 10.1530/EJE-20-0299.

25. Liberati A., Altman D.G., Tetzlaff J., Mulrow C., Gøtzsche P.C., Ioannidis J.P., Clarke M., Devereaux P.J., Kleijnen J., Moher D. The PRISMA statement for reporting systematic reviews and meta-analyses of studies that evaluate health care interventions: explanation and elaboration. J. Clin. Epidemiol., 2009, vol. 62, no. 10, pp. e1-e34. DOI: 10.1016/j.jclinepi.2009.06.006.

26. Biggin A., Munns C.F. Osteogenesis imperfecta: diagnosis and treatmen. Curr. Osteoporos. Rep. 2014. Vol. 12, no. 3. pp. 279-288. DOI: 10.1007/ s11914-014-0225-0

27. Marini J.C., Blissett A.R. New genes in bone development: what's new in osteogenesis imperfecta. J. Clin. Endocrinol. Metab., 2013, vol. 98, no. 8, pp. 3095-3103. DOI: 10.1210/jc.2013-1505.

28. Bregou Bourgeois A., Aubry-Rozier B., Bonafé L., Laurent-Applegate L., Pioletti D.P., Zambelli P.Y. Osteogenesis imperfecta: from diagnosis and multidisciplinary treatment to future perspectives. Swiss Med. Wkly., 2016, vol. 146, pp. w14322. DOI: 10.4414/smw.2016.14322.

29. Burtsev M.E., Frolov A.V., Logvinov A.N., Ilin D.O., Korolev A.V. Sovremennyi podkhod k diagnostike i lecheniiu detei s nesovershennym osteogenezom [Current approach to diagnosis and treatment of children with osteogenesis imperfecta]. Ortopediia, Travmatologiia i Vosstanovitelnaia Khirurgiia Detskogo Vozrasta, 2019, vol. 7, no. 2, pp. 87-102. (in Russian) DOI: 10.17816/PTORS7287-102.

30. Cho T.J., Ko J.M., Kim H., Shin H.I., Yoo W.J., Shin C.H. Management of Osteogenesis Imperfecta: A Multidisciplinary Comprehensive Approach. Clin. Orthop. Surg., 2020, vol. 12, no. 4, pp. 417-429. DOI: 10.4055/cios20060

31. Steiner R.D., Basel D. COL1A1/2 Osteogenesis Imperfecta. In: GeneReviews ${ }^{\circledR}$ [Internet]. Adam M.P., Ardinger H.H., Pagon R.A., et al., editors. Seattle (WA), University of Washington, 1993-2021. 2005. Available at: https://www.ncbi.nlm.nih.gov/sites/books/NBK1295/

32. Lim J., Grafe I., Alexander S., Lee B. Genetic causes and mechanisms of osteogenesis imperfecta. Bone, 2017, vol. 102, pp. 40-49. DOI: 10.1016/j. bone.2017.02.004.

33. Orioli I.M., Castilla E.E., Barbosa-Neto J.G. The birth prevalence rates for the skeletal dysplasias. J. Med. Genet., 1986, vol. 23 , no. 4, pp. 328-332. DOI: $10.1136 /$ jmg.23.4.328.

34. Stevenson D.A., Carey J.C., Byrne J.L., Srisukhumbowornchai S., Feldkamp M.L. Analysis of skeletal dysplasias in the Utah population. Am. J. Med. Genet A, 2012, vol. 158A, no. 5, pp. 1046-1054. DOI: 10.1002/ajmg.a.35327.

35. Folkestad L., Hald J.D., Canudas-Romo V., Gram J., Hermann A.P., Langdahl B., Abrahamsen B., Brixen K. Mortality and causes of death in patients with osteogenesis imperfecta: a register-based nationwide cohort study. J. Bone Miner. Res., 2016, vol. 31, no. 12, pp. 2159-2166. DOI: 10.1002/jbmr.2895.

36. Kuurila K., Kaitila I., Johansson R., Grénman R. Hearing loss in Finnish adults with osteogenesis imperfecta: a nationwide survey. Ann. Otol. Rhinol. Laryngol., 2002, vol. 111, no. 10, pp. 939-946. DOI: 10.1177/000348940211101014.

37. Ward L.M., Rauch F., Travers R., Chabot G., Azouz E.M., Lalic L., Roughley P.J., Glorieux F.H. Osteogenesis imperfecta type VII: an autosomal recessive form of brittle bone disease. Bone, 2002, vol. 31, no. 1, pp. 12-18. DOI: 10.1016/s8756-3282(02)00790-1.

38. Cabral W.A., Barnes A.M., Adeyemo A., Cushing K., Chitayat D., Porter F.D., Panny S.R., Gulamali-Majid F., Tishkoff S.A., Rebbeck T.R., Gueye S.M., Bailey-Wilson J.E., Brody L.C., Rotimi C.N., Marini J.C. A founder mutation in LEPRE1 carried by $1.5 \%$ of West Africans and $0.4 \%$ of African Americans causes lethal recessive osteogenesis imperfecta. Genet. Med., 2012, vol. 14, no. 5, pp. 543-555. DOI: 10.1038/gim.2011.44.

39. Kurt-Sukur E.D., Simsek-Kiper P.O., Utine G.E., Boduroglu K., Alanay Y. Experience of a skeletal dysplasia registry in Turkey: a five-years retrospective analysis. Am. J. Med. Genet. A, 2015, vol. 167A, no. 9, pp. 2065-2074. DOI: 10.1002/ajmg.a.37122.

40. Marini J.C., Forlino A., Cabral W.A., Barnes A.M., San Antonio J.D., Milgrom S., Hyland J.C., Körkkö J., Prockop D.J., De Paepe A., Coucke P., Symoens S., Glorieux F.H., Roughley P.J., Lund A.M., Kuurila-Svahn K., Hartikka H., Cohn D.H., Krakow D., Mottes M., Schwarze U., Chen D., Yang K., Kuslich C., Troendle J., Dalgleish R., Byers P.H. Consortium for osteogenesis imperfecta mutations in the helical domain of type I collagen: regions rich in lethal mutations align with collagen binding sites for integrins and proteoglycans. Hum. Mutat., 2007, vol. 28, no. 3, pp. 209-221. DOI: $10.1002 /$ humu.20429.

41. Ishikawa Y., Bachinger H.P. A molecular ensemble in the rER for procollagen maturation. Biochim. Biophys. Acta, 2013, vol. 1833, no. 11, pp. 24792491. DOI: 10.1016/j.bbamcr.2013.04.008.

42. Rauch F., Moffatt P., Cheung M., Roughley P., Lalic L., Lund A.M., Ramirez N., Fahiminiya S., Majewski J., Glorieux F.H. Osteogenesis imperfecta type V: marked phenotypic variability despite the presence of the IFITM5 c.-14C > T mutation in all patients. J. Med. Genet., 2013, vol. 50, no. 1, pp. 21-24. DOI: 10.1136/jmedgenet-2012-101307.

43. Semler O., Garbes L., Keupp K., Swan D., Zimmermann K., Becker J., Iden S., Wirth B., Eysel P., Koerber F., Schoenau E., Bohlander S.K., Wollnik B., Netzer C. A mutation in the 5'-UTR of IFITM5 creates an in-frame start codon and causes autosomal-dominant osteogenesis imperfecta type V with hyperplastic callus. Am. J. Hum. Genet., 2012, vol. 91, no. 2, pp. 349-357. DOI: 10.1016/j. ajhg.2012.06.011.

44. Morello R., Bertin T.K., Chen Y., Hicks J., Tonachini L., Monticone M., Castagnola P., Rauch F., Glorieux F.H., Vranka J., Bächinger H.P., Pace J.M., Schwarze U., Byers P.H., Weis M., Fernandes R.J., Eyre D.R., Yao Z., Boyce B.F., Lee B. CRTAP is required for prolyl 3- hydroxylation and mutations cause recessive osteogenesis imperfecta. Cell, 2006, vol. 127, no. 2, pp. 291-304. DOI: 10.1016/j.cell.2006.08.039. 
45. OMIM. Online Mendelian Inheritance in Man®. An Online Catalog of Human Genes and Genetic Disorders. Available at: https://omim.org/ phenotypisSeries/PS166200.

46. Sillence D.O., Senn A., Danks D.M. Genetic heterogeneity in osteogenesis imperfecta. J. Med. Genet., 1979 , vol. 16, no. 2, pp. $101-116$. DOI: $10.1136 /$ jmg.16.2.101.

47. Sillence D.O., Rimoin D.L., Danks D.M. Clinical variability in osteogenesis imperfecta-variable expressivity or genetic heterogeneity. Birth Defects Orig. Artic. Ser., 1979, vol. 15, no. 5B, pp. 113-129.

48. Thomas I.H., DiMeglio L.A. Advances in the Classification and Treatment of Osteogenesis Imperfecta. Curr. Osteoporos. Rep., 2016, vol. 14, no. 1, pp. 1-9. DOI: 10.1007/s11914-016-0299-y.

49. Skryabin E.G., Komarova I.V., Bukseev A.N., Kukarskaya I.I., Akselrov M.A., Khramova E.B., Suprunets S.N., Popkov D.A. Vnutriutrobnye perelomy kostei skeleta u plodov s nesovershennym osteogenezom: obzor literatury i sobstvennoe klinicheskoe nabliudenie [Intrauterine bone fractures in fetuses with osteogenesis imperfecta: a literature review and a case report]. Genij Ortopedii, 2018, vol. 24, no. 4, pp. 521-529. DOI: 10.18019/1028-4427-2018-24-4-521-529.

50. McAllion S.J., Paterson C.R. Causes of death in osteogenesis imperfecta. J. Clin. Pathol., 1996, vol. 49, no. 8, pp. 627-630. DOI: 10.1136/ jcp.49.8.627.

51. Mingazov E.R., Chibirov G.M., Popkov D.A. Ortopedicheskie oslozhneniia i iatrogenii pri korrektsii deformatsii nizhnikh konechnostei u patsientov, stradaiushchikh tiazhelymi formami nesovershennogo osteogeneza [Orthopaedic complications and iatrogenies during deformity correction of lower limbs in patients with severe osteogenesis imperfecta]. Genij Ortopedii, 2018, vol. 24, no. 2, pp. 168-176. DOI: 10.18019/1028-4427-2018-24-2$168-176$.

52. Glorieux F.H., Rauch F., Plotkin H., Ward L., Travers R., Roughley P., Lalic L., Glorieux D.F., Fassier F., Bishop N.J. Type V osteogenesis imperfecta: a new form of brittle bone disease. J. Bone Miner. Res., 2000, vol. 15, no. 9, pp. 1650-1658. DOI: 10.1359/jbmr.2000.15.9.1650.

53. Rohrbach M., Giunta C. Recessive osteogenesis imperfecta: clinical, radiological, and molecular findings. Am. J. Med. Genet. C. Semin. Med. Genet., 2012, vol. 160C, no. 3, pp. 175-189. DOI: 10.1002/ajmg.c.31334.

54. Van Dijk F.S., Cobben J.M., Kariminejad A., Maugeri A., Nikkels P.G., Van Rijn R.R., Pals G. Osteogenesis Imperfecta: A Review with Clinical Examples. Mol. Syndromol., 2011, vol. 2, no. 1, pp. 1-20. DOI: 10.1159/000332228.

55. De Paepe A., Malfait F. The Ehlers-Danlos syndrome, a disorder with many faces. Clin. Genet., 2012, vol. 82, no. 1, pp. 1-11. DOI: 10.1111/j.13990004.2012.01858.x.

56. Aglan M.S., Hosny L., El-Houssini R., Abdelhadi S., Salem F., Elbanna R.A., Awad S.A., Zaki M.E., Temtamy S.A. A scoring system for the assessment of clinical severity in osteogenesis imperfecta. J. Child. Orthop., 2012, vol. 6, no. 1, pp. 29-35. DOI: 10.1007/s11832-012-0385-3.

57. Bonafe L., Cormier-Daire V., Hall C., Lachman R., Mortier G., Mundlos S., Nishimura G., Sangiorgi L., Savarirayan R., Sillence D., Spranger J., Superti-Furga A., Warman M., Unger S. Nosology and classification of genetic skeletal disorders: 2015 revision. Am. J. Med. Genet. A, 2015, vol. 167A, no. 12, pp. 2869-2892. DOI: 10.1002/ajmg.a.37365.

58. Bardai G., Moffatt P., Glorieux F.H., Rauch F. DNA sequence analysis in 598 individuals with a clinical diagnosis of osteogenesis imperfecta: diagnostic yield and mutation spectrum. Osteoporos. Int., 2016, vol. 27, no. 12, pp. 3607-3613. DOI: 10.1007/s00198-016-3709-1.

59. Tauer J., Robinson M.E., Rauch F. Osteogenesis imperfecta: new perspectives from clinical and translational research. JBMR Plus, 2019, vol. 3, no. 8, pp. e10174. DOI: 10.1002/jbm4.10174.

60. Jones M., Breakwell L., Cole A., Arundel P., Bishop N. Type V osteogenesis imperfecta undergoing surgical correction for scoliosis. Eur. Spine J., 2018, vol. 27, no. 9, pp. 2079-2084. DOI: 10.1007/s00586-018-5465-8.

Received: 28.06 .2021

\section{Information about the authors:}

1. Sergey O. Ryabykh, M.D., Ph.D.,

Ilizarov National Medical Research Centre for Traumatology and Orthopedics, Kurgan, Russian Federation, ORCID: 0000-0002-8293-0521,

Email: rso_@mail.ru

2. Dmitry A. Popkov, M.D., Ph.D., Professor of RAS, correspondent member French Academy of Medical Sciences, Ilizarov National Medical Research Centre for Traumatology and Orthopedics, Kurgan, Russian Federation, ORCID: 0000-0002-8996-867X,

Email: dpopkov@mail.ru

3. Elena N. Shchurova, Ph.D. of Biological Sciences,

Ilizarov National Medical Research Centre for Traumatology and Orthopedics, Kurgan, Russian Federation, Email: elena.shurova@mail.ru

4. Polina V. Ochirova, M.D., Ph.D.,

Ilizarov National Medical Research Centre for Traumatology and Orthopedics, Kurgan, Russian Federation, ORCID: 0000-0001- 5172-4429,

Email: poleen@yandex.ru

5. Tat'iana V. Ryabykh, M.D., Ilizarov National Medical Research Centre for Traumatology and Orthopedics, Kurgan, Russian Federation, ORCID: 0000-0002-9315-3035, Email: rtatav@rambler.ru 